\title{
Растительность федерального заказника «Удыль» (Нижнее Приамурье)
}

\author{
П.С. Ван ${ }^{1 凶}$, А. В. Силаев ${ }^{2}$, Г. В. Ван ${ }^{1}$ \\ 'Заповедное Приамурье, Российская Федерация \\ (681000, Хабаровский край, г. Комсомольск-на-Амуре, пр. Мира, 54) \\ ${ }^{2}$ Институт географии СО РАН им. В.Б. Сочавы, Российская Федераџия \\ (664033, г. Иркутск, ул. Улан-Баторская, 1)
}

\begin{abstract}
Аннотация: Цель - инвентаризация растительности и построение карто-схемы растительности заказника «Удыль».

Материалы и методы. Работа выполнена на основе полевых исследований 2014-2019 годов, данных дистанционного зондирования и цифровой модели рельефа. При полевых исследованиях использованы методы закладки комплексных пробных площадей и маршрутного описания растительности.

Результаты и обсуждение. В статье представлена карто-схема растительности федерального заказника «Удыль» масштаба 1:500 000, впервые построенная для этой территории. Она характеризует распределение основных типов растительности. Растительность заказника сложена представителями восточно-сибирской, охотско-камчатской и маньчжурской флоры. С помощью карты выявлено, что лесная растительность заказника составляет $25 \%$ его площади и произрастает в низкогорной части, а также вдоль пойм рек. Территория заказника сильно пострадала от пожаров разных лет. В связи с этим здесь наиболее распространены помимо коренных производные лиственничные леса ( $11 \%$ от площади заказника), вторичные белоберезовые и осиновые леса (10\%). Лиственничные леса представлены 3 типами - травяные, горно-кустарниковые и багульниковые; вторичные мелколиственные леса 2 типами - вейниковые и осоковые. Горно-кустарниковые лиственничники включают в себя редкие для заказника виды сосудистых растений. Зональные елово-пихтовые леса произрастают небольшими группами (1,5\%), образуя зеленомошные, травянисто-зеленомошные и зеленомошно-папоротниковые типы леса. Небольшую площадь занимают интразональные долинные ивняки вейниковые (2\%), елово-пихтово-широколиственные и тополевые леса (2\%). Последние отличаются наибольшим флористическим разнообразием в заказнике и наличием в составе древостоя высокобонитетных пород деревьев таких как Populus maximowiczii A. Hehry. В заказнике фрагментарно представлены дубняки полынно-вейниковые и осоковые, занимающие верхние участки крутых склонов южной экспозиции и крутые скалистые склоны, выходящие к озеру Удыль. Лугово-болотная растительность наиболее распространена в заказнике (49\%) и покрывает его низменную часть. Она состоит из растительности верховых вересковых кустарничково-сфагновых болот $(36 \%)$ и вейниковых, осоково-вейниковых и осоковых лугов, часто переходящих в травяные болота (13\%). Первый тип растительности произрастает на надпойменных террасах, подстилаемых глинистыми отложениями, второй - в поймах рек, впадающих в озеро Удыль. Менее 1\% площади заказника приходится на кустарниковую, скальную, водную растительность и растительность временных песчаных наносов.

Заключение. Растительность заказника «Удыль» характеризуется бедностью флористического состава и растительных группировок. Растительность является типичной для Нижнего Приамурья.
\end{abstract}

Ключевые слова: болото, луг, лиственничные леса, елово-пихтовые леса, южная тайга, карта, озеро.

Для цитирования: Ван П.С., Силаев А.В., Ван Г.В. Растительность федерального заказника «Удыль» (Нижнее Приамурье) // Вестник Воронежского государственного университета. Серия: География. Геоэкология, 2021, № 3, c. 69-78. DOI: https://doi.org/10.17308/geo.2021.3/3603

(C) Ван П.С., Силаев А.В., Ван Г.В., 2021

$\triangle$ Ван Полина Сергеевна, e-mail: vanpolina8710@mail.ru

cc) (i) Контент доступен под лицензией Creative Commons Attribution 4.0 License.

Вестник ВГУ, Серия: География. Геоэкология, 2021, № 3, 69-78 


\section{ВВЕДЕНИЕ}

Инвентаризация растительности - одна из первостепенных научных задач для особо охраняемых природных территорий (ООПТ), поскольку создает основу для всех последующих исследований. Результаты таких работ создают базу для оценки биоразнообразия и степени антропогенной трансформации ООПТ, что позволяет разработать адекватные меры для их охраны.

Несмотря на более чем 30-ти летнюю историю и международное признанное заказника «Удыль», его растительность остается на сегодня малоизученной. Опубликована обобщающая работа по физико-географической характеристике территории [6], вышли из печати статьи по флоре cocyдистых растений $[3,4]$, и ландшафтам заказника $[5,7]$, где приводится поверхностное описание растительности. Специальных геоботанических работ, выполненных в заказнике, не проводилось.

Цель публикации - провести инвентаризацию растительных сообществ заказника «Удыль» с отображением их на карте.

\section{МАТЕРИАЛЫ И МЕТОДЫ}

Заказник «Удыль» первоначально основан как республиканский (региональный) в 1988 году в Ульчском районе Хабаровского края. Цель организации - сохранение, восстановление редких и исчезающих видов растений и животных. С 1994 года территория заказника отнесена к водно-болотным угодьям (ВБУ) мирового значения («Озеро Удыль и устья рек Бичи, Битки и Пильда»), на которую распространяется действие Рамсарской конвенции. Заказник имеет исключительное значение для миграции перелетных птиц как место отдыха и гнездования [6]. В 2009 году заказнику присвоен федеральный статус. Его площадь равна 134,2 тыс. га.

Заказник «Удыль» расположен в северо-западной части Удыль-Кизинской низменности. Рельеф охраняемой территории преимущественно озерно-аллювиальный низменный, частично низкогорный. Низменная часть заказника покрыта верховыми болотами и осоково-вейниковыми лугами на торфяно-глееземах и аллювиальных почвах. По схеме геоботанического районирования площадь заказника располагается в южной подзоне хвойных лесов. Низкогорную часть, занимающую $18 \%$ площади заказника, покрывают преимущественно лиственничные и елово-пихтовые леса, а также производные от них березовые и осиновые на буроземах. В центре заказника находится пресноводное озеро Удыль, занимающее $24 \%$ его площади. Озеро ограничено низкими заболочен- ными берегами с юга и обрывистыми высокими берегами с северо- и юго-востока.

В летние сезоны 2014, 2016, 2018 и 2019 годов в заказнике «Удыль» проведены полевые ландшафтно-экологические исследования с закладкой и описанием 40 геоботанических пробных площадей размером 20х20 метров, а также дополнительным описанием растительности на маршруте общей протяженностью 107 км. Пробные площади заложены в различных типах локальных местоположений - геотопах. Геотопы образуют систему местных ландшафтных сопряжений, - от элювиальных и трансэлювиальных типов местоположений до аккумулятивных и супераквальных. По каждому растительному ярусу детально описан видовой состав. Учет древесных пород проведен путем подсчета числа стволов, произрастающих на площадке, отдельно по каждому виду. Определены морфометрические параметры лесообразующих пород. С помощью бурава Пресслера установлен их возраст. По полученным данным рассчитан бонитет пород деревьев. Для всего древесного полога определена полнота, а для кустарникового и травяно-кустарничкового ярусов вычислены средняя высота и проективное покрытие (ПП). Для каждого вида указано обилие по шкале Друде. По собранным материалам и литературным источникам [13] составлен конспект растительности заказника «Удыль». Растительные группировки выделены нами по доминантной классификации. Названия растений приведены в соответствии с указанным источником [14]. В ходе полевых работ на геоботанических пробных площадях было заложено и описано 40 почвенных профилей. Типы почв определялись на основе профильно-генетической классификации почв России [11].

С помощью полевого материала, данных дистанционного зондирования (ДД3), а также при использовании цифровой модели рельефа была построена карто-схема растительности заказника. Морфометрический анализ рельефа территории проводился на основе модели Shuttle Radar Topographic Mission (SRTM), созданной на большую часть поверхности земного шара. Ее данные представляют собой матрицу высот с размером ячейки 3 угловые секунды (около 90 м). В данной работе использованы обновленные, более точные данные SRTM 4-й версии. На основе SRTM-модели был произведен расчет крутизны, поляризации и экспозиции склонов. Совмещая в QGIS все построенные поверхности, можно в любой точке определить основные показатели рельефа (абсо- 
лютные высоты, углы наклона, освещенность, координаты), что в дальнейшем также легло в основу создания различных картографических слоев на территорию заказника.

ДД3 являются объективной, оперативной и многоцелевой информацией о земной поверхности. Они содержат суммарную информацию обо всех компонентах ландшафта, определяющих его дистанционное изображение. В основном для картографирования заказника использовалась спектрозональная съемка системы, Landsat 7 ETM+, Landsat 8. Исследователями часто используется комбинация каналов 7-4-2, дающая изображение, близкое к естественным цветам. При обработке изображений с Landsat 8 применялась аналогичная комбинация 7-5-3, соответствующая комбинации каналов на Landsat 7 (7-4-2). Визуальное дешифрирование склеенных многоканальных файлов с использованием различных комбинаций каналов и учетом прямых и косвенных дешифровочных признаков (четкие очертания, линейные границы и т. п.) позволило на начальном этапе выявить границы контуров с различными типами растительности и границы земель, пройденных пожарами.

\section{РЕЗУЛЬТАТЫ И ОБСУЖДЕНИЕ}

Построенная карто-схема растительности заказника «Удыль» демонстрирует распределение основных типов растительности ООПТ. Лесная растительность занимает менее 1/4 площади заказника и произрастает преимущественно в его низкогорной части, а также вдоль пойм рек. Характерные типы почв - бурозем и бурозем грубогумусовый. Зональные лесные формации в заказнике - елово-пихтовые леса. Многочисленные пожары сильно трансформировали растительный покров. Сегодня в мозаике лесов большую часть занимают вторичные белоберезовые и осиновые, а также коренные и производные лиственничные леса.

Лиственничные леса наиболее распространены в заказнике среди лесной растительности. Они занимают около $11 \%$ от его площади (здесь и далее указывается процентное значение от площади заказника, которая рассчитана с учетом гидрологических объектов). Значительная часть лесов - вторичные, возникшие после пожаров. Для заказника характерны 3 типа лиственничников - травяные, горно-кустарниковые и багульниковые.

Лиственничники травяные (вейниковые и осоково-вейниковые) чаще всего встречаются в заказнике. Они произрастают на пологих и средней крутизны склонах гор и увалах, останцовых сопках и подгорных шлейфах. Полнота насаждений 0,4-0,5. В молодых послепожарных лиственничниках с классом бонитета III обычными спутниками Larix cajanderi являются Betula platyphylla Sukaczev и Sorbus amurensis Koehne. Здесь кустарниковый ярус развит хорошо - ПП до $70 \%$. Доминируют Sorbaria sorbifolia A. Braun и Rosa acicularis Lindl. В хорошо развитом травяном покрове (ПП 70-80\%) абсолютные доминанты Calamagrostis amurensis Prob. и Carex pallida C.A. Меу. В спелых лиственничниках с классом бонитета IV-V кустарниковый ярус практически отсутствует. Здесь древостой состоит полностью из Larix cajanderi. Такие монодоминантные лиственничники характерны для пологих вершин и склонов хребтов Гидали и Межозерный.

Лиственничники багульниковые произрастают на выположенных переувлажненных межгорных понижениях на буроземах грубогумусовых, иногда оподзоленных, и торфяно-глееземах с линзами вечной мерзлоты. Они в основном относятся к коренной интразональной растительности [12]. В древостое к лиственнице часто примешивается Betula platyphylla. Полнота 0,3. Преобладающий класс бонитета IV-V. Кустарниковый ярус очень густой - ПП 90\%. В нем абсолютно доминирует Ledum maximum (Nakai) A.P. Khokhr. \& Mazurenko. В редком травяном покрове (ПП до $30 \%$ ) доминирует осока.

Лиственничники горно-кустарниковые (рододендроновые и можжевельниковые) редко представлены в заказнике. Они произрастают на привершинных крутых и средней крутизны склонах. Древостой помимо лиственницы включает Populus tremula L. и Betula platyphylla. Полнота небольшая - 0,2-0,5. Класс бонитета лиственницы III-IV. Ее возобновление удовлетворительное. Кустарниковый ярус средней густоты - ПП до 40\%. В нем доминируют Rhododendron dauricum L., реже Juniperus sibirica Burgsd. В подлеске также представлены Spiraea ussuriensis Pojark., Rosa acicularis, Duschekia fruticosa (Rupr.) Pouzar. Tpaвяно-кустарничковый ярус, несмотря на небольшое ПП (10-40\%), очень разнообразен. Здесь можно встретить как обычные для заказника виды - Rhodococcum vitis-idaea (L.) Avrorin, Artemisia maximovicziana Krasch. ex Poljakov, Moehringia lateriflora (L.) Fenzl, Trifolium lupinaster L., Maianthemum bifolium (L.) F.W. Schmidt, Hemerocallis middendorffii Trautv. \& C.A. Mey., Calamagrostis amurensis, a также такие редкие, 


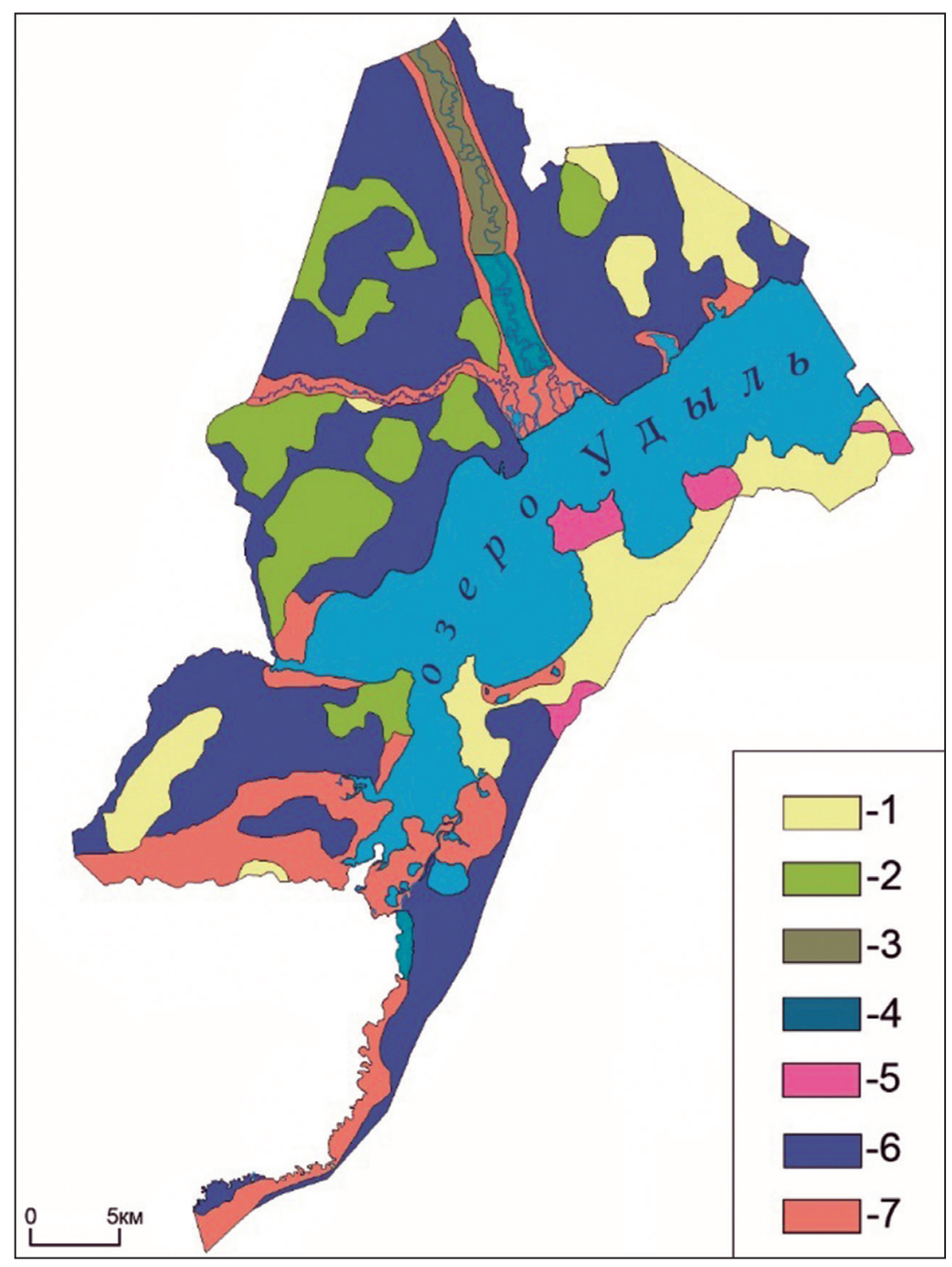

Рuc. Карта растительности заказника «Удыль» Условные обозначения.

Лесная растительность. 1. Лиственничные, березово-лиственничные и дубово-лиственничные леса вейниковые, осоковые, багульниковые и рододендровые. 2. Вторичные березовые и осиновые травяные леса с участием Larix cajanderi Mayr с зарослями малины, шиповника и таволги. 3. Долинные елово-пихтовошироколиственные и тополевые леса кустарниково-разнотравные с Fraxinus mandshurica Rupr.

4. Долинные ивняки вейниковые с участием Betula platyphylla и Populus maximowiczii. 5. Елово-пихтовые леса зеленомошные и травяно-зеленомошные.

Лугово-болотная растительность. 6. Верховые вересковые кустарничково-сфагновые болота с редкими лиственницами, иногда с элементами низинных травяных болот.

7. Вейниковые, осоково-вейниковые и осоковые луга, в том числе сырые и переходящие в низинные травяные болота часто с зарослями Betula ovalifolia Rupr. и Salix brachypoda (Trautv. \& C.A. Mey.) Kom.

[Fig. Udyl nature reserve vegetation map

\section{Legend sheet:}

Forest vegetation. 1. Reedgrass, sedge, swamp ledum's, and rhododendron's hemlock, birch-hemlock, and oak-hemlock forests; 2. Grass second-growth birch and aspen forests with Larix cajanderi, clumps of raspberry,

brier, and spiraea; 3. Shrubby and rich in herbs lowland mixed coniferous-broad-leafed and poplar forests with Fraxinus mandshurica; 4. Reedgrass lowland osier-beds with Betula platyphylla and Populus maximowiczii; 5. Green moss and grassy-green moss fir forests.

Meadow-boggy vegetation. 6. High moor heath dwarf shrub bogs with rare larches, sometimes with elements of flat grassy bogs; 7 . Reedgrass, sedge-reedgrass, and sedge meadows including meadows grading in flat grassy bogs often with brushwoods of Betula ovalifolia and Salix brachypoda] 
как Scorzonera radiata Fisch. ex Ledeb., Epipactis papillosa Fisch. ex Ledeb., Ophelia tetrapetala (Pall.) Grossh.

Поскольку территория несколько раз выгорала, то около $10 \%$ площади заказника занимают вторичные белоберезовые и осиновые осоковые и вейниковые леса. Они произрастают в местах, ранее занятых лиственничниками и ельниками. Особую группу образуют релочные леса из березы и осины, растущие узкими полосами вдоль приустьевых участков рек. В древостое доминирует Betula platyphylla, реже Populus tremula, примешивается также Larix cajanderi. Лесообразующие породы, как правило, имеют низкий класс бонитета - I-II. Полнота низкая - 0,4. В подросте хорошо возобновляется лиственница, иногда ель. Кустарниковый ярус (ПП 30-50\%) представлен светолюбивыми видами - Rhododendron dauricum, Duschekia fruticosa, Sorbaria sorbifolia, Rubus sachalinensis H. Lev., Rosa acicularis и различными видами таволги и жимолости. В хорошо развитом травянистом покрове преобладают Calamagrostis amurensis или Carex pallida.

Наибольшим флористическим разнообразием отличаются пойменные высокобонитетные елово-пихтово-широколиственные и тополевые леса (2\% от площади заказника), занимающие узкие прибрежные полосы нижнего течения реки Бичи на богатых питательными веществами аллювиальных почвах. В древостое первого типа леса доминирует Fraxinus mandshurica Rupr. До $40 \%$ от состава древостоя занимают ель и пихта. Редкий кустарниковый ярус состоит из Sorbaria sorbifolia, Ribes triste Pall., Swida alba (L.) Opiz. Травяной покров густой и разнотравный. В нем много Calamagrostis amurensis, Cacalia hastata L. и Cacalia auriculata DC.

Тополевые леса в основном представлены Populus maximowiczii I и II класса бонитета. В густом кустарниковом ярусе массово произрастает Swida alba. Разнотравный травянистый ярус реже, чем в елово-пихтово-широколиственных насаждениях (ПП 40\%). В нем обычны Matteuccia struthiopteris (L.) Tod., Calamagrostis langsdorffii (Link) Trin., Urtica angustifolia Fisch. ex Hornem., Filipendula palmata (Pall.) Maxim.

В нижнем течении рек иловато-супесчаные прирусловые террасы заняты ивняками (Osier) вейниками, которые составляют $2 \%$ от площади заказника. Древостой редкостойный состоит преимущественно из Salix rorida Laksch., часто с участием Betula platyphylla и Populus maximowiczii.
Подлеска практически нет. Травяной покров густой с доминированием вейника.

Сохранившиеся елово-пихтовые леса произрастают небольшими группами на покатых поверхностях подгорных шлейфов и нижних частях пологих затененных склонов, в долинах ключей и рек. Они занимают около $2 \%$ от площади заказника. Елово-пихтовые насаждения представлены 3 типами - зеленомошные, травянисто-зеленомошные и зеленомошно-папоротниковые. Они выделяются составом и ПП травяного покрова. Помимо Picea ajanensis Fisch. ex Carr. и Abies nephrolepis (Trautv.) Maxim. к составу древостоя часто примешиваются Larix cajanderi и Betula platyphylla, в поймах рек - Sorbus amurensis, Fraxinus mandshurica, Acer mono Maxim. ex Rupr. Преобладающий класс бонитета III-IV, в елово-пихтовых зеленомошно-папоротниковых лесах до V. Полнота до 0,6-0,8. Кустарниковый ярус практически отсутствует.

В елово-пихтовых зеленомошных и травянисто-зеленомошных насаждениях травяной покров представлен незначительно. Он характеризуется низким ПП до $30 \%$. Структуру леса в основном составляют Chamaepericlymenum canadense (L.) Asch. \& Graebn., Equisetum sylvaticum L., Maianthemum bifolium, Trientalis europaea L., Smilacina dahurica Turcz. ex Fisch. \& C.A. Mey., Linnaea borealis L., Pyrola rotundifolia L., Orthilia secunda (L.) House.

B елово-пихтовых зеленомошно-папоротниковых лесах травяно-кустарничковый ярус отличается большим разнообразием. Здесь доминируют Smilacina dahurica и Gymnocarpium dryopteris (L.) Newman. Помимо видов, характерных для предыдущего типа леса, появляются Paris verticillata M. Bieb., Aconitum umbrosum (Korsh.) Kom., Aruncus dioicus (Walter) Fernald, Trigonotis peduncularis (Trevir.) Benth. ex Baker \& S. Moore, Polypodium sibiricum Sipliv., Chimaphila umbellata (L.) W.P.C. Barton, Saussurea dubia Freyn. ПП травостоя - 50-70\%. В поврежденных пожарами ельниках 50-60-летней давности ель и пихта успешно возобновляются, вытесняя лиственницу и березу.

Широколиственные леса в заказнике распространены фрагментарно и представлены дубняками полынно-вейниковыми и осоковыми. Чистых дубняков мало. Для верхних участков крутых склонов южной экспозиции, а также для так называемых «быков» - крутых скалистых склонов, выходящих к озеру, - обычны дубово-лиственничные и дубо- 
во-осиновые леса. Зачастую они являются вторичными, что подтверждается наличием пирогенных остатков в маломощных скелетных почвах, на которых они восстанавливаются. Здесь молодые дубы (Quercus mongolica Fisch. ex Ledeb.) от 30-70 лет, высотой, как правило, до 8-10 м, с классом бонитета I-II, соседствуют с уцелевшей от пожара Larix cajanderi возрастом 120-140 лет с классом бонитета III-IV. Полнота небольшая - 0,2-0,5. Кустарниковый ярус плохо выражен (ПП 5 \%) и состоит из Rosa acicularis, Spiraea media Schmidt и Rhododendron dauricum. В густом травяно-кустарничковом ярусе доминируют осоки и Calamagrostis amurensis. Значительна роль Artemisia maximovicziana, A. medioxima Krasch. ex Poljakov, Lathyrus humilis (Ser.) Spreng., Maianthemum bifolium, Convallaria keiskei Miq., Hemerocallis middendorffii и Rhodococcum vitis-idaea.

Болотная растительность заказника занимает $43 \%$ его площади. Здесь можно выделить 2 основных типа болот - кустарничково-сфагновые и травяные.

Кустарничково-сфагновые болота занимают $36 \%$. Сфагновые покрывают надпойменные террасы, сложенные глинистыми отложениями. Такие болота формируются в условиях застойного увлажнения на торфяно-болотных почвах и торфяно-глееземах в условиях близко расположенной к поверхности вечной и сезонной мерзлоты. В роли основного эдификатора выступают сфагновые мхи. В кустарничково-сфагновых и кустарничково-осоково-сфагновых болотах произрастают вересковые кустарнички и кустарники Chamaedaphne calyculata (L.) Moench, Vaccinium uliginosum L., Ledum palustre, Myrica tomentosa (DC.) Asch. \& Graebn. На отдельных участках представлена Betula fruticosa Pall.

Растительность травяных болот занимает примерно $7 \%$ от площади заказника. Она произрастает преимущественно на поймах рек, впадающих в озеро Удыль, в местах залегания торфяно-болотных почв с линзами сезонной и вечной мерзлоты. Часто это сырые луга, перешедшие из-за длительного застойного увлажнения в стадию травяных болот. В питании основную роль играют паводковые и аллювиальные воды [12]. Основными эдификаторами травяных болот (осоковых и вейниковых) являются Calamagrostis langsdorffi, Carex schmidtii Meinsh., C. minuta Franch. Высота травостоя достигает 1,5 метра. Из других растений травяно-кустарничкового яруса встречаются Sanguisorba parviflora (Maxim.) Takeda, Iris setosa
Pall. ex Link, Fimbripetalum radians (L.) Ikonn. Кyстарниковый ярус изреженный и не всегда представлен.

Отдельно следует выделить зыбунные болота, развивающиеся в низкой пойме приустьевых участков рек на аллювиальных глеевых почвах. Здесь основной доминант - Eleocharis palustris (L.) Roem. \& Schult. Высота травостоя 30 см. Другие растительные ярусы отсутствуют.

Луговая растительность покрывает низменную часть заказника. Она занимает около $6 \%$ площади; характеризуется однообразным флористическим составом. Основными доминантами выступают Calamagrostis langsdorffi, C. angustifolia Kom. и Carex appendiculata (Trautv. \& C.A. Mey.) Kük., C. schmidtii, C. rigidioides (Gorodkov) V.I. Krecz. В заказнике можно выделить три типа лугов - вейниковые, осоковые и смешанные вейниково-осоковые, произрастающие на аллювиальных гумусовых почвах, подстилаемых песчаными отложениями, часто в условиях близко расположенных линз вечной и сезонной мерзлоты. В зависимости от степени увлажнения почв меняется флористический состав лугов. На сухих лугах доминируют вейники и чаще представлена кустарниковая растительность (ПП 20\%) из Betula fruticosa, Salix gracilistyla Miq. и Spiraea salicifolia L. На переувлажненных лугах доля осоки в травостое возрастает. Травянистый ярус густой и достигает высоты 1 метра. Помимо вейника и осоки в травянистом ярусе могут встречаться Fimbripetalum radians, Inula britannica L., Sanguisorba parviflora, Lathyrus pilosus Cham., Lagedium sibiricum (L.) Soják.

Кустарниковая растительность представлена зарослями Salix udensis Trautv. \& C.A. Mey., S. brachypoda (Trautv. \& C.A. Mey.) Kom., Betula ovalifolia Rupr., B. fruticosa. Сомкнутость зарослей достигает 90\%. Высота кустарников от 0,5 до 4 метров. В густом травяном покрове доминируют вейники и осоки. Кустарники окаймляют луга и травяные болота на низменных берегах озера Удыль. Этот тип растительности не отражен на карте поскольку занимает менее 0,5\% площади заказника.

Северо- и юго-восточное побережье озера Удыль окантовано обрывистыми берегами (западный склон хребта Гидали и гора Удыль, мыс Жолмых) с развитой на них скальной растительностью. Разреженный растительный покров представлен травянистыми ксерофитами, среди которых наиболее встречающимися являются Poa stepposa (Krylov) Roshev., Calamagrostis monticola Petrov ex Kom., Allium maackii (Maxim.) Prokh. ex 
Kom., Aizopsis middendorfiana (Maxim.) Grulich, Saxifraga bronchialis L. Из кустарников произрастают Juniperus davurica, Rhododendron dauricum, Sorbaria sorbifolia, Spiraea ussuriensis, образующие заросли на более пологих нижних и верхних частей склонов. Скальная растительность также занимает менее $0,5 \%$ площади заказника.

Растительность песчаных наносов низкой поймы приустьевых участков рек (протока Ухта, Большая и Малая Силасу) представлена редкими небольшими группировками травянистых растений. Из-за высокой динамичности аккумуляционных аллювиальных процессов эти участки поймы практически лишены гумусового горизонта. Их верхняя корнеобитаемая часть (до глубины 1520 см) характеризуется сухостью, что способствует развитию здесь ксерофильных растений: Dianthus versicolor Fisch. ex Link, Agrostis trinii Turcz., Calamagrostis amurensis, Allium maximowiczii Regel, Artemisia commutata Besser и другие. Такие группировки растительности являются непостоянными и со временем переходят в луговой тип.

Водную растительность озера Удыль формируют 4 вида растений: Nymphoides peltata (S.G. Gmel.) Kuntze, Sagittaria natans Pall., Sparganium angustifolium Michx. и Trapa natans L., приспособленные к произрастанию в условиях переменного уровня воды. Наибольшее видовое разнообразие гидрофитов сосредоточено в мелководных заливах северо-восточной части озера и в заливах протоки Ухта, где из-за значительного ослабления ветро-волнового воздействия складываются благоприятные условия обитания для водных сосудистых растений (5-8 видов). Здесь же отмечена высокая степень зарастания, которая составляет $30-40 \%$. В заливах южной части озера и устьевых участках рек видовой состав очень беден (1-5), а степень зарастания колеблется до 10-15\% [1].

Растительность заказника «Удыль» типична для Нижнего Приамурья. Сходства наблюдаются с Эворон-Чукчагирской и Чля-Орельской низменностями, расположенными в 180 км западнее и 110 км севернее границ заказника «Удыль» соответственно и с территорией низовья реки Амгунь, с озерами Джевдуха, Конди и Далган, что находятся в 60 км северо-восточнее. Однако подробных исследований растительности здесь не проводилось. Несколько научных публикаций дают общую картину физико-географической характеристики этих районов $[6 ; 14]$. Территории сложены травянистыми и вересково-кустарничковыми болотами и вейниково-осоковыми лугами. Поло- жительные формы рельефа низменностей заняты лиственничными и вторичными белоберезовыми и осиновыми, реже елово-пихтовыми лесами. Впадающие в озера реки окаймляют ольховники и ивняки. В отличие от заказника «Удыль» в составе лесной растительности берегов озера Эворон и поймах рек, впадающих в него, встречаются частично пострадавшие от пожаров сосняки. В тоже время для этих водно-болотных угодий отсутствуют данные о широколиственных лесах.

Интересным для сравнения с растительностью заказника является территория заповедника «Комсомольский», расположенная в южной части Нижнеамурской провинции в 170 км юго-западнее заказника «Удыль». Для заповедника характерен более сложный среднегорно- и низкогорно-долинный рельеф. Основной водный объект - устье реки Горин. Заповедник находится на границе южно-таежных и хвойно-широколиственных лесов, занимающих здесь около 85 \% его площади. Распространены елово-пихтовые, лиственничные, кедрово-широколиственные, дубовые, смешанные широколиственные, вторичные белоберезовые и осиновые леса, фрагментарно ольховники и ивняки $[2,8,9,10]$. Оставшиеся $15 \%$ площади покрывают осоково-вейниковые луга, болотная растительность, расположенная в пониженных участках пойм (травянистые и кустарничково-сфагновые группировки), скальная и кустарниковая растительность. Леса Комсомольского заповедника отличаются от заказника «Удыль» помимо появлением более южных растительных сообществ (кедрово-широколиственные и смешанные широколиственные леса), многоярусностью и большим флористическим разнообразием (688 видов сосудистых растений в Комсомольском заповеднике и 425 в заказнике «Удыль»). Как видим, растительность центральной и южной частей в пределах одной физико-географической провинции имеет существенные различия. Такие особенности связаны с более южным широтным положением, сравнительно мягким муссонно-континентальным климатом, а также разнообразным рельефом заповедника «Комсомольский» в сравнении с заказником. Кроме того, территория заповедника хотя и пострадала от лесных пожаров, но в значительно меньшей степени, чем заказник «Удыль».

\section{ЗАКЛЮЧЕНИЕ}

Примерно половина площади заказника занята интразональной растительностью, в большей степени сфагново-кустарничковыми и травяными 
болотами, в меньшей - осоковыми, вейниковыми и вейниково-осоковыми лугами. Болота занимают преимущественно первую надпойменную террасу, отличающуюся слабым дренажем и застойным увлажнением. Луга покрывают слабодренируемые пойменные пространства на аллювиальных отложениях.

Лесные сообщества в заказнике занимают около $27 \%$ площади и сосредоточены в его восточной низкогорной части. Зональная растительность, сохранившаяся на небольшой площади - темнохвойные елово-пихтовые леса южной тайги. Однако на незначительное распространение их по территории повлияли особенности рельефа и пирогенная трансформация растительности. Следует отметить, что в ельниках, поврежденных пожарами с небольшой давностью (50-60 лет), возобновление ели и пихты проходит успешно.

К интразональной коренной лесной растительности относятся заболоченнные лиственничники багульниковые. Из-за череды пожаров, прошедших здесь в разные годы, установить какие из лиственничников относятся к коренным, а какие к вторичным, затруднительно. Лиственничные и вторичные белоберезовые и осиновые леса доминируют в заказнике.

Растительность заказника сложена представителями восточно-сибирской и охотско-камчатской флоры, реже маньчжурской. Она характеризуется бедностью флористического состава и растительных группировок, что является следствием выположенного рельефа, заболоченностью, суровостью климатических условий, близко расположенной сезонной и вечной мерзлоты, а также антропогенной нарушенностью территории. Наибольшим флористическим разнообразием отличаются пойменные елово-пихтово-широколиственные и тополевые леса с большой долей участия в них видов маньчжурской флоры. Интересны в флористическом отношении горно-кустарниковые лиственничники, в которых, несмотря на разреженный растительный покров, включены редкие для заказника виды.

Растительность заказника «Удыль» типична для Нижнего Приамурья и во многом схожа с водно-болотными угодьями региона.

\section{СПИСОК ЛИТЕРАТУРЫ}

1. Бобров А. А., Черемис Е.В. Изучение водных сосудистых растений бассейна озера Удыль // Летопись природы: Инвентаризация и мониторинг природныхх комплексов заказника «Удыль», 2017, книга 1, с. 147-152.

2. Ван В. М. Сосудистые растения Комсомольского заповедника (Хабаровский край) // Комаровские чте-

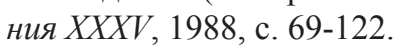

3. Ван Г. В., Ван В. М., Ван П. С., Кондратьева Е. В. К флоре заказника «Удыль» // Вестник Северо-Восточного научного иентра ДВО РАН, 2019, № 2, с. 55-62.

4. Ван Г.В. Новые материалы по флоре заказника Удыль (Хабаровский край) // Бюллетень Ботанического сада-института ДВО РАН, 2011, № 8, с. 4-13.

5. Ван П.С., Юрикова Е.А. Информационно-статистическое моделирование организации лесных геосистем Нижнего Приамурья (на примере заказника «Удыль») // Материаль Международной научно-практической конференции, посвященной памяти чл.-корр. РАН А.Н. Антипова «Географические основы и экологические принципь региональной политики природопользования», 2019, с. 769-772.

6. Водно-болотные угодья России. Водно-болотные угодья Дальнего Востока России / Под ред. В.Н. Бочарникова. Москва: Wetlands International, 2005, том 5. 220 с.

7. Петренко П. С. Лесные гео- и экосистемы заказника «Удыль» // Материаль шестой научно-практической конференции «Геосистемы в Северо-Восточной Азии: типы, современное состояние и перспективы развития», 2018, с. 218-222.

8. Петренко П.С. Особенности ландшафтной структуры заповедника «Комсомольский» // Вестник ДВО РАН, 2018, №2, с. 95-100.

9. Петренко П.С., Ван Г.В. Лесные сообщества заповедника «Комсомольский» // Материалы ХII Дальневосточной конференции по заповедному делу, 2017 с. 55-57.

10 Петренко П.С., Коломыц Э.Г. Влияние геоморфологических факторов на организацию лесных топогеосистем заповедника «Комсомольский» // Becmник Воронежского государственного университета. Серия: География, Геоэкология, 2018, №2, С.16-27.

11. Полевой определитель почв России. Москва: Почвенный институт, 2008. 150 с.

12. Природные условия Удыль-Кизинской низменности / Под ред. А.М. Ивлева. Новосибирск: Наука, 1973. 192 с.

13. Пронкевич В.В., Крюкова М.В., Махинов А.Н. Водно-болотное угодье «Озеро Эворон и река Эвур» как новая форма особо охраняемых природных территорий Хабаровского края // Материальь 2-й региональной научной конференции: Биоразнообразие и проблемы экологии Приамурья и сопредельных территорий, 2016, с. 27-32.

14. Флора российского Дальнего Востока. Владивосток: Дальнаука, 2006. 455 с.

Конфликт интересов: Авторы декларируют отсутствие явных и потенциальных конфликтов интересов, связанных с публикацией настоящей статьи.

Поступила в редакиию 16.11.2020 Принята к публикаиии 03.09.2021 


\title{
Vegetation of Udyl Federal Nature Reserve (Lower Priamurie)
}

\author{
P.S. Van ${ }^{1}$, A.V. Silaev ${ }^{2}$, G.V. $\operatorname{Van}^{1}$ \\ ${ }^{1}$ Federal State-Funded Institution "Zapovednoye Priamurye”, Russian Federation \\ (54, Mir Ave., Khabarovsky krai, Komsomol'sk-on-Amur, 681000) \\ ${ }^{2} V$. B. Sochava Institute of Geography SB RAS, Russian Federation \\ (1, Ulan-Batorskaya St., Irkutsk, 664033)
}

\begin{abstract}
Purpose: Inventory of the vegetation and creation of the map-scheme of the vegetation of Udyl nature sanctuary.

Materials and methods: The title has been written on basis of 2014-2019 field work research data, remotely-sensed data and digital terrain model. During field work researching the methods of the estimation by indicator plots and line description of vegetation were used.

Results and discussions: The map-scheme of vegetation was presented in this article for Udyl federal nature sanctuary compiled for this territory for the first time. Scale 1:500 000. The map shows general types of vegetation distribution in the sanctuary. Nature sanctuary vegetation includes East-Siberian, Okhotsk-Kamchatka and Manchurian floral forms. On basis of the map we found out that forest vegetation of the sanctuary occupies $25 \%$ of its area and grows in the low-mountain part of the sanctuary and along rivers. Forest fire during last years in a row caused great damage to the sanctuary's territory. That's why radical and derivative hemlock forests (11\% of the sanctuary's area) and second-growth birch and aspen forests $(10 \%)$ predominate here. Hemlock forests include 3 forest types - grassy, mountain-shrubby, and swamp ledum ones. Second-growth small-leaved forest includes 2 forest types - small reed and sedge ones. Mountain-shrubby hemlock forests include rare vascular plant species for the sanctuary. Zonal fir forests grow in small groups $(1,5 \%)$ and form green moss, grass green moss, and green moss ferny forest types. Intrazonal valley osier-beds $(2 \%)$, mixed coniferous-broad-leafed forests, and poplar forests ( $2 \%)$ occupy small area. The mixed coniferous-broad-leafed and poplar forests have large floristic diversity. They consist trees with good bonitet - Populus maximowiczii. Sagebrush-reedgrass and sedge oakeries grow rarely in the sanctuary. They occupy top sites of steep adret slopes and steep rocky slopes facing the lake Udyl'. Meadow boggy vegetation grows throughout the territory $(49 \%)$ and covers its low-land part. It consists of vegetation of high moor heath dwarf shrub bogs (36\%) and reedgrass, sedge-reedgrass, and sedge meadows which often go into grassy bogs $(13 \%)$. High moor bog's vegetation covers terraces above flood-plain with argillaceous deposits. Grass meadow's and bog's vegetation covers floodplain of rivers which disgorge their waters into Udyl' lake. Less than $1 \%$ of the sanctuary's area is shrub, rock, aquatic, and temporary sand bar's vegetation.

Conclusion: The vegetation of Udyl sanctuary is characterised by poor floristic composition and plant aggregation. The vegetation of Udyl sanctuary is typical for Lower Priamurie.
\end{abstract}

Key words: bog, meadow, hemlock forests, spruce forests, southern taiga, map, lake.

For citation: Van P. S., Silaev A. V., Van G. V. Vegetation of Udyl Federal Nature Reserve (Lower Priamurie). Vestnik Voronezskogo gosudarstvennogo universiteta. Seria: Geografia. Geoekologia, 2021, no. 3, pp. 69-78. (In Russ.) DOI: https://doi.org/10.17308/geo.2021.3/3603

\section{REFERENCES}

1. Bobrov A.A., CHeremis E. V. Izucheniye vodnykh sosudistykh rasteniy ozera Udyl [Researching of water vascular plants in Udyl' lake basin]. Letopis prirody: Inventarizatsiya i monitoring prirodnykh kompleksov zaka$z n i k a \ll U d y l », 2017$, no. 1, pp. 147-152. (In Russ.)
2. Van V.M. Sosudistyye rasteniya Komsomolskogo zapovednika (Khabarovskiy kray) [Vascular plants of Komsomolsky nature reserve (Khabarovsky krai)]. Komarovskiye chteniya, 1988, no. 35, pp. 69-122. (In Russ.)

3. Van G.V., Van V.M., Van P. S., Kondrateva E.V. K flore zakaznika «Udyl» [To flora of Udyl' nature re-

(C) Van P. S., Silaev A. V., Van G. V., 2021

$\triangle$ Polina S. Van, e-mail: vanpolina8710@mail.ru

The content is available under Creative Commons Attribution 4.0 License. 
serve]. Vestnik Severo-Vostochnogo nauchnogo tsentra DVO RAN, 2019, no. 2, pp. 55-62. (In Russ.)

4. Van G. V. Novyye materialy po flore zakaznika Udyl (Khabarovskiy kray) [New information about flora of Udyl nature reserve (Khabarovsky krai)]. Byulleten Botanicheskogo sada-instituta DVO RAN, 2011, no. 8, pp. 4-13. (In Russ.)

5. Van P. S., Yurikova E.A. Informatsionno-statisticheskoye modelirovaniye organizatsii lesnykh geosistem Nizhnego Priamuria (na primere zakaznika «Udyl») [Informational statistic modeling of forest geosystems' organization for the Low Priamurye territory (by the example of Udyl' nature reserve)]. Materialy Mezhdunarodnoy nauchno-prakticheskoy konferentsii. posvyashchennoy pamyati chl.-korr. RAN A.N. Antipova "Geograficheskiye osnovy $i$ ekologicheskiye printsipy regionalnoy politiki prirodopolzovaniya», 2019, pp. 769-772. (In Russ.)

6. Vodno-bolotnyye ugodia Rossii. Vodno-bolotnyye ugodia Dalnego Vostoka Rossii [Russian wetlands. Wetlands of the Southern part of Russian Far East]. Moscow: Wetlands International, 2005, part 5. 220 p. (In Russ.)

7. Petrenko P.S. Lesnyye geo- i ekosistemy zakaznika «Udyl» [Forest geo- and ecosystems of Udyl nature reserve]. Materialy shestoy nauchno-prakticheskoy konferentsii «Geosistemy v Severo -Vostochnoy Azii: tipy. sovremennoye sostoyaniye i perspektivy razvitiya», 2018, pp. 218-222. (In Russ.)

8. Petrenko P.S. Osobennosti landshaftnoy struktury zapovednika «Komsomolskiy» [Landscape structure features of Komsomolsky nature reserve]. Vestnik DVO RAN, 2018, no. 2, pp. 95-100. (In Russ.)

9. Petrenko P.S., Van G.V. Lesnyye soobshchestva zapovednika «Komsomolskiy» [Forests of Komsomolsky

\section{Ван Полина Сергеевна}

кандидат географических наук, старший научный сотрудник филиала Комсомольский ФГБУ «Заповедное Приамурье», г. Комсомольск-на-Амуре, Хабаровский край, Российская Федерация, ORCID: 0000-0001-75887003, e-mail: vanpolina8710@mail.ru

Силаев Антон Владимирович

кандидат географических наук, научный сотрудник ФГБУН Института географии СО РАН им. В.Б. Сочавы, г. Иркутск, Российская Федерация, ORCID: 00000001-7611-5910, e-mail: anton_s@bk.ru

Ван Григорий Владимирович

кандидат биологических наук, руководитель филиала Комсомольский ФГБУ «Заповедное Приамурье», г. Комсомольск-на-Амуре, Хабаровский край, Российская Федерация, ORCID: 0000-0002-7875-4035, e-mail: vangrigoriy@mail.ru nature reserve]. Materialy XII Dalnevostochnoy konferentsii po zapovednomu delu, 2017, pp. 55-77. (In Russ.)

10. Petrenko P.S., Kolomyts E. G. Vliyaniye geomorfologicheskikh faktorov na organizatsiyu lesnykh topogeosistem zapovednika «Komsomolskiy» [Influence geomorfological factors on organization of Komsomolsky nature reserve's forest geosystems]. Vestnik Voronezhskogo gosudarstvennogo universiteta. Seria: Geografia. Geoekologia, 2018, no. 2, pp. 16-27. (In Russ.)

11. Polevoy opredelitel pochv Rossii [Field identificator of soils of Russia]. Moscow: Soil Institute, 2008. $150 \mathrm{p}$. (In Russ.)

12. Prirodnyye usloviya Udyl-Kizinskoy nizmennosti [Geographical description of Udyl'-Kizinskaya lowland]. Novosibirsk: Nauka, 1973. 192 p. (In Russ.)

13. Pronkevich V.V., Kryukova M.V., Mahinov A.N. Vodno-bolotnoye ugodye «Ozero Evoron i reka Evur» kak novaya forma osobo okhranyayemykh prirodnykh territoriy Khabarovskogo kraya ["Evoron lake and Evur river" wetland as a new form of specially protected territories in Khabarovsk territory]. Materialy 2-y regionalnoy nauchnoy konferentsii: Bioraznoobraziye i problemy ekologii Priamuria i sopredelnykh territoriy, 2016, pp. 27-32. (In Russ.)

14. Flora rossiyskogo Dalnego Vostoka [Flora of Russian Far East]. Vladivostok: Dalnauka, 2006. 455 p.

Conflict of interests: The authors declare no information of obvious and potential conflicts of interest related to the publication of this article.

Received: 16.11.2020

Accepted: 03.09.2021

Polina S. Van

Cand. Sci. (Geogr.), Senior Researcher in Komsomol'sky brunch, Federal State-Funded Institution "Zapovednoye Priamurye", Komsomol'sk-on-Amur, Khabarovsky krai, Russian Federation, ORCID: 0000-0001-7588-7003, e-mail: vanpolina8710@mail.ru

Anton V. Silaev

Cand. Sci. (Geogr.), Research officer of V.B. Sochava Institute of Geography SB RAS, Irkutsk, Russian Federation, ORCID: 0000-0001-7611-5910, e-mail: anton_s@bk.ru

Grigory V. Van

Cand. Sci. (Biol.), Branchwork manager of Komsomol'sky brunch, Federal State-Funded Institution "Zapovednoye Priamurye", Khabarovsky krai, Russian Federation, ORCID: 0000-0002-7875-4035, e-mail: vangrigoriy@ mail.ru. 